\title{
Financing Development Through Public Private Partnerships (PPPs) in Botswana
}

\author{
BOTLHALE, E.K.
}

\section{Abstract}

argely due to chronic fiscal stress since Lthe recent global economic crisis, there are calls for alternative ways of financing economic development. Public Private Partnerships (PPPs) have been identified as such alternatives. There is an increasing awareness that the private sector is not a competitor but a strategic partner in the drive for economic development. Therefore, governments are leveraging on the benefits of PPPs. Using the case study of Botswana, which is experiencing revenue challenges as diamonds have not been selling well since 2008, this theoretical paper explores the possibility of using more PPPs to finance economic development. Grounded in interpretivist research methodology, using the survey research strategy and using secondary data sources in the form of a desk survey, it concluded that there is a case for the increased use PPPs to finance economic development. It further concluded that while there is demonstrated appetite for PPPs, to date, only a few projects have been procured through PPPs. Hence, moving forward, and given the deteriorating revenue situation, there is a need to use more PPPs to deliver economic development. Finally, the paper argues that there is a need to reform the current PPP legal-institutional architecture and bench-mark and peer-learn from best PPP practices in Africa such as South Africa and Nigeria and beyond.

Keywords: Public Private Partnerships (PPPs); Developmental PPPs; Economic Development; Botswana. 
Financing Development through Public Private Partnerships (PPPs) in Botswana 27

\section{Introduction}

In the recent past, PPPs have been used to procure public works and services all over the world (Colverson, 2011; Osbourne, 2000; United Nations, 2008). Although initially restricted to public infrastructure in the form of roads, railways, prisons, government buildings, power generation, or water and waste treatment facilities, PPP has increasingly moved into the provision of so-called "social infrastructure" such as schools, hospitals, and health services (Colverson, 2011:3). There is a reason to believe that PPPs will continue in their ascendancy and will overshadow the traditional/conventional public procurement model where the government provides the sole financing for projects. Two key factors that drive the use of PPPs include public sector reforms such as New Public Management (particularly, the drive to run a government like a business à la Gore (1993) as well as the chronic fiscal stress that occurred after the recent global economic crisis. Other factors are insufficient investment, growing pressures on government budgets and a general concern about service provision by state enterprises and agencies (African Development Bank Group, 2015). The private sector possesses better mobility than the public sector; the government lacks the ability of raising massive funds for the largescale infrastructure projects, but private participation can mitigate the government's financial burden (Walker et al., 1995). The private sector will get to know the needs of the public sector client and over time; and the private sector has more to offer than the public sector in terms of skills, technology and knowledge therefore providing better quality facilities (Ghobadian et al., 2004).

PPPs confer many varied benefits, for example: improve the quality and quantity of basic infrastructure such as the provision of water and its treatment, energy supply and transportation; can be widely applied to a variety of public services such as hospitals, schools, prisons and government accommodation; construction is being completed to plan and to budget; helping the public sector develop a more disciplined and commercial approach to infrastructure development whilst allowing them to retain strategic control of the overall project and service (International Project Finance Association, 2015). However, this is not to say that PPPs are problem-free; they are freighted with problems. However, with the right legal and regulatory framework for PPPs, technical skills to manage the PPPs and proper project design, they can confer many and varied benefits to countries that adopt them (National Council for PublicPrivate Partnerships, 2016; United Nations, 2008). 
In view of the many benefits of PPPs, Botswana has adopted PPPs. The idea of PPPs took root after the adoption of the Privatisation Policy of Botswana in 2000 (Republic of Botswana, 2000). Through the Privatisation Policy, which reform policy was not externally imposed but a result of a self-decision by the government to engender the 3-Es of management being efficiency, effectiveness and economy (Botlhale, 2014), the government chose to scale down the frontiers of the state. Even though privatisation is yet to take place in earnest as instanced by the stalled privatisation of Air Botswana and the yet-to-take-place privatisation of the National Development Bank and Botswana Telecommunications Corporation, there have been efforts to adopt PPPs. As far back as 2009, the Cabinet approved the PPP Policy but there has been a slow uptake of PPPs (Mannathoko, 2012; Mohohlo, 2011). However, of late, there has been an upsurge in the uptake of PPPs as sufficiently instanced by the building of shopping malls, for example, Rail Park Mall in Gaborone (BR Properties, 2015) and Mongala Mall in Kanye (Botswana Press Agency, 2014a). BR Properties (Pty) Ltd, a division of Botswana Railways, partnered with Bifm, Eris Botswana and Tredinnick to build the Rail Park Mall on September 2010 and the mall was opened on the 24 April 2012 (BR Properties, 2015). The Mongala Mall is a PPP venture between the Southern District Council and Time Projects (Botswana Press Agency, 2014a) and was officially opened on 26 March 2014 (Botswana Press Agency, 2014b).

Given the importance of PPPs, particularly in resource-constrained Botswana since 2008 (see, for example, Gaolathe [2009] and Mathambo [2010-16]), it is important that the subject be given sufficient attention in the literature. In this regard, there is a dearth of literature on PPPs in Botswana; some of the only available works being Mpabanga (2011) and, Rao and Vokolkova (2007). This is the gap in the Botswana-specific literature on PPPs and, so, this paper aims to add to the burgeoning literature on PPPs in Botswana.

The paper is organised as follows. It reviews the literature on PPPs. Secondly, it discusses methods (data collection and analysis methods). Thirdly, it discusses the evolution of the PPPs framework in Botswana. Fourthly, it discusses examples of PPP projects in Botswana. Fourthly, it discusses fiscal stress and the increasing case for the use for PPPs. Fifthly, it discusses practical issues to consider when implementing PPPs in Botswana and concludes. 
Financing Development through Public Private Partnerships (PPPs) in Botswana 29

\section{Literature Review on PPPs}

The term Public-Private Partnerships (PPPs), alternatively called Private Sector Participation (PSP), Private Participation in Infrastructure (PPI) and P3 ${ }^{1}$, means different things to different people. There is no universally-accepted definition of a PPP (Cruz and Marques, 2013; Forrer et al., 2010; International Monetary Fund, 2004; OECD, 2013; Public-Private Infrastructure Advisory Facility, 2008). Therefore, it suffers from definitional difficulties and ambiguities. Despite these difficulties, the term is variously defined as next illustrated by various authors such as the International Monetary Fund (2004); OECD (2002); Savas (2000); South African National Treasury (2004); and Public-Private Infrastructure Advisory Facility (2008). Public-Private Partnerships (PPPs) refer to:

- Arrangements where the private sector supplies infrastructure assets and services that traditionally have been provided by the government" (International Monetary Fund, 2004:4).

- A long-term agreement between the government and a private partner where the service delivery objectives of the government are aligned with the profit objectives of the private partner" (OECD, 2002:2).

- Any arrangement between government and the private sector in which partially or traditionally public activities are performed by the private sector (Savas, 2000:4).

- A contract between a public sector institution and a private party, in which the private party assumes substantial financial, technical and operational risk in the design, financing, building and operation of a project (South African National Treasury, 2004: 4-5).

- A long-term contract between a government and a private entity for provision of a public service" (Public-Private Infrastructure Advisory Facility, 2008:1).

- The provision of services by the private sector on behalf of the State following the fulfilment of design and build responsibilities (Colverson, 2011:2).

\footnotetext{
${ }^{1}$ P3 is a term widely used in Canada. For instance, the National Council for Public-Private Partnerships (2016:1) defines P3 as "a contractual arrangement between a public agency (federal, state or local) and a private sector entity."
} 
Public-Private Partnerships (PPPs) are not a new phenomenon; neither did they necessarily grow out of public sector reforms such as privatisation and outsourcing. Early records of PPPs are traced to the time of the Roman Empire [27 BC-AD 476]; for example, the use of private tax and toll road collectors (Forrer et al., 2010). However, the use of PPPs saw phenomenal growth in the early 1990s with the advent of public sector reforms such as New Public Management with derivatives such as privatisation and outsourcing (see, e.g., Savas, 2000). No matter how PPPs are defined, they are a collaborative partnership between the public and private sectors. The partnership is premised on the allocation of resources, risks, responsibilities and rewards between collaborative partners (Canadian Council for PPPs, 2010). Like other initiatives, the delivery of PPPs is securely predicated on some success factors (National Council for Public-Private Partnerships, 2016; United Nations, 2008). For instance, the National Council for Public-Private Partnerships (2016) lists these success factors:

1) Public sector champion: recognized public figures should serve as the spokespersons and advocates for the project and the use of a P3.

2) Statutory environment: there should be a statutory foundation for the implementation of each partnership.

3) Public sector's organized structure: the public sector should have a dedicated team for P3 projects or programs.

4) Detailed contract (business plan): this contract should include a detailed description of the responsibilities, risks and benefits of both the public and private partners.

5) Clearly defined revenue stream: while the private partner may provide a portion or all of the funding for capital improvements, there must be an identifiable revenue stream sufficient to retire this investment and provide an acceptable rate of return over the term of the partnership.

6) Stakeholder support: ...it is important to communicate openly and candidly with these stakeholders to minimize potential resistance to establishing a partnership. 
Financing Development through Public Private Partnerships (PPPs) in Botswana 31

7) Pick your partner carefully: .... candidate's experience in the specific area of partnerships being considered is an important factor in identifying the right partner. Equally, the financial capacity of the private partner should be considered in the final selection process

There are different types of PPPs and examples are: Build-Own-Maintain (BOM); Build-Own-Operate (BOO); Build-Develop-Operate (BDO); Design-Construct-ManageFinance (DCMF); Design-Build-Operate (DBO); Buy-Build-Operate (BBO); and Lease-OwnOperate [LOO] (OECD, 2008; Posner et al., 2009:5). The most common form of PPP is Design-Construct-Manage-Finance (DCMF) in which the private sector finances, builds and operates the asset for a period of many years, often ranging from 20 to 50 years (Posner et al., 2009:5). Whatever type form the PPP entity assumes, the following are key common characteristics: a long-term agreement between a government entity and a private company, under which the private company provides or contributes to the provision of a public service; and at the end of the PPP contract the associated assets revert to government ownership (Public-Private Infrastructure Advisory Facility, 2008:2).

PPPs are generally developed for public interest missions, including government entering into partnership with the private sector in order to construct roads, railways, ports, airports, water and wastewater, waste, energy, health, security and prisons (Cruz and Marques, 2013:1). Other areas are: transportation, hospitals, prisons and schools (Posner et al. 2009); infrastructure assets (for example, bridges and roads) and more complex assets [prisons, utilities] (Dewulf et al., 2011; OECD, 2002; Osbourne, 2000). Worthy of mention are PPPs in the health sector. While the provision of healthcare is widely perceived as a public good, 'private capital and expertise are increasingly viewed as essential resources for increasing efficiency, expanding access to services and introducing innovative technologies (O'Hanlon Health Consulting et al., 2013). Hence, the challenge for governments is to strike a judicious mix of public and private capital to finance health services. To illustrate, in Botswana, the Bill and Melinda Gates Foundation and Merck Co. Inc./the Merck Company Foundation, a Public Private Partnership (PPP) between the Government of Botswana, was established in 2000 (Ramiah and Reich, 2006). The partnership, one of the most successful health PPPs in Africa, complements the government's efforts to fight the HIV/AIDS pandemic in Botswana. 
PPPs confer benefits to the contracting parties, that is, the private sector and public sector, each of whom is actuated by different motives to engage in PPP arrangements (Jones, 1994). The private sector has an explicit bottom line; which is maximisation of profits. On the other hand, the public sector (or government) does not have a monetary bottom line but a non-monetary bottom line being public service maximisation. The non-monetary bottom line is grounded in legislation, regulation, political opinion, democratic decision-making, minimising risk and maximising the social value (see Jones, 1994). PPPs confer some of the following benefits: increased efficiency in project delivery, and operation and management; availability of additional resources to meet the growing needs of investment in the sector; and access to advanced technology (United Nations, 2011:2); better management of capital spending; innovation in design, construction, operation and maintenance over the life of the contract; creating greater efficiencies and synergies between design and operation; and better management of risk (Southern African Development Community, 2010:3).

As pointed out by the IMF (2006), PPPs have other benefits which could be realised under the realm of risk-sharing. PPPs allow for risk-sharing in the following areas: construction risk (delays and cost overruns); financial risk (increases in financing costs); availability risk (threats to the continuous supply of capital services); demand risk (potential shortfalls in use of the asset by the public); and force majeure [risks from natural or man-made disasters and war] (International Monetary Fund, 2006:20).

PPPs projects are not problem-free. There are potential problems. Hence, there are many important economic, social, political, legal, and administrative factors which need to be carefully assessed before approvals of PPPs are considered by the government (United Nations, 2011; Zucker, 1977). Also, not all projects are PPP-feasible; "the private sector may not take interest in a project due to perceived high risks or may lack technical, financial or managerial capacity to implement the project"; and, finally, the "PPP project may be costlier unless additional costs (due to higher transaction and financing costs) can be off-set through efficiency gains" (United Nations, 2011:3). Therefore, the partners must pay heed to success factors; e.g., see Jacobson and Choi (2008) and Trafford and Proctor (2006). In this regard, Trafford and Proctor (2006) identified five key success factors: good communication, openness, effective planning, ethos and direction. Similarly, the Canadian Council for PPPs (2010) has identified determinants of P3 success in Canada: (i) a stable pipeline; the P3 market has seen 
Financing Development through Public Private Partnerships (PPPs) in Botswana 33

strong growth in terms of the number of new projects that have entered the market since 2009; (ii) efficient procurement; of the mature P3 markets around the world, Canada is acknowledged to have one of the most efficient procurement processes; and (iii) a diverse market for project finance; government purchasers at the provincial level have ensured that project documents are consistent across all projects in an asset class.

PPP projects have witnessed ascendancy in both developed and developing countries and are considered drivers of economic growth (see; e.g., Montanheiro, 2014) and "game-changers for solving development problems" (Centre for International and Strategic Studies, 2011:vi). The developed countries are leading in this regard. Arguably, the best-developed programme is the UK's Private Finance Initiative (PFI) which began in 1992 (Cheung et al., 2009; HM Treasury, 2012; IMF, 2004). Since the UK is the one of the first adopters of the PPP regime, several countries have bench-marked against it when designing their PPP programmes (Dewulf et al., 2011). Other countries with significant PPP programmes include Australia, Ireland, USA, Canada and EU members such as Finland, Germany, Greece, Italy, the Netherlands, Portugal and Spain (International Monetary Fund, 2004). There are examples of exemplar PPP case studies, particularly, noted for their sustainability. Examples are:

(i) a desalination plant in the State of Victoria, Australia;

(ii) Arlanda Express, Sweden;

(iii) Dublin Docklands Development Authority, Ireland; and

(iv) Vancouver Landfill, Canada (see Colverson, 2011).

The developing world, particularly Sub-Saharan Africa, is not entirely lagging behind as instanced by PPP regimes in power houses such as Nigeria (e.g., see Okonkwo et al., 2014) and South Africa (e.g., see Dewulf et al., 2011). Examples of major PPPs in Africa are: the Global Rural Electrification Program, Morocco (Colverson, 2001); Egypt (the design, financing, construction and operation of a secondary treatment stage for the Abu Rawash Wastewater Treatment Plant, and the operation and maintenance of the existing primary treatment facilities with a capacity of 1.2 million $\mathrm{m} 3 /$ day); Nigeria (the establishment of a US\$30 million 100-bed referral hospital and primary gateway clinic in Calabar); Sierra Leone (an agricultural and renewable energy project that will produce $90,000 \mathrm{~m}^{3}$ of ethanol per year, being the first bio fuels project to be successfully project financed on the African continent) (Eversheds International, 2014); South 
Africa/Mozambique (N4 Toll Road from South Africa to Mozambique); Mozambique (Maputo Port); South Africa (water provision in the Dolphin Coast/llembe District; Municipality Prison Contracts; and eco-tourism concession in the Kruger National Park); Uganda (telecommunications sector); Gabon (multi-utility provision); and Tanzania [Graft Taints power purchasing agreement] (Farlam, 2005). It is of note that in Africa, "South Africa has the greatest cumulative experience of public-private partnerships in Africa, with over 50 such partnerships in development or implementation at national or provincial level, and 300 projects at municipal level, since 1994" (Farlam, 2005:1).

Ending, a question can be asked, 'which is the best procurement method for public developmental projects? Traditional or PPP procurement model? The answer is not unambiguous; it depends. However, when the PPP procurement model is well designed, it eclipses the traditional procurement method because it offers more VfM (Value for Money) if it is applied through innovative tools such as the value-based Performance Information Procurement System [PIPS] (see; e.g., Kashiwagi [2011] on PIPS). However, this is to say that PPP models are problem free. These are problems associated with PPP projects and when "they fail, the public opinion is quick to condemn a PPP that does not succeed as a failure of the concept itself: (Grimsey and Lewis, 2007:171). So, design issues are of vital importance.

\section{Methods}

This is a theoretical paper which is grounded in published research literature in PPP with the overarching aim of furthering the fledgling PPP literature in Botswana. It used secondary data sources in the form of a desk survey. The paper used a variety of data collection sources, among them, policy documents, for example, National Development Plan 9 (Ministry of Finance and Development Planning, 2003), Privatisation Policy of Botswana (2000), Public-Private Partnership Policy and Implementation Framework (2009) and Budget Speeches (Gaolathe, 2009; Mathambo, 2010-16). It used the descriptive approach and the tool used was document analysis. The analysis helped the author to answer the following questions: (i) how did the PPP regime evolve in Botswana? and (ii) what factors account for the increasing need for PPPs in Botswana? Finally, the analysis helped lay the foundation for recommendations to enhance the financing of development in Botswana through PPPs. 
Financing Development through Public Private Partnerships (PPPs) in Botswana 35

\section{Evolution of PPPs framework in Botswana}

PPPs were, for a long time after the discovery and exploitation of minerals, particularly diamonds in the 1970s, not part of public finance discourse in Botswana. However, this line of thinking underwent a major rethink in the 2000s after the promulgation of the Privatisation Policy of Botswana in 2000 (Republic of Botswana, 2000). Through the 2002/2003 Budget Speech, themed Implementing Public Sector Reforms. a way forward for sustainable economic diversification, (Gaolathe, 2002) and the National Development Plan 9 [2003/04/2008/09] (Ministry of Finance and Development Planning, 2003), the government announced that PPPs would be used extensively as a form of procuring and financing infrastructure projects in the public sector. The idea also found its way into the crafting of Vision 2016 (Botswana Vision Council, 2010). To grow and develop the Vision, the government emphasised the importance of smart partnerships between the public and private sectors. However, discussions about PPPs found outmost expression during the 2000 National Business conference (Land, 2002). The theme of the conference was 'Public-Private Partnership in Development - Towards Vision 2016. When officially opening conference in Francistown on 14 August, then President, Festus Mogae, stated that smart partnerships would, amongst other things, help the country deliver Vision 2016 (Botswana Press Agency, 2000). In a similar vein, the introduction to the conference report states that:

The success of public-private partnership is contingent on government and the private sector working together. While it is ultimately businesses that will innovate and create jobs...there is much government can do. Government has increasingly recognised that it is vital to energise the private sector and open doors for private initiative to accelerate economic growth. Both sectors must have mutual trust and act responsibly to achieve this common goal without putting self-interest above the common goal (quoted from Land (2002:7)).

To give impetus to the PPP regime, the Ministry of Finance and Development Planning commissioned a consultancy to develop the PPPs framework in 2005. A year later, the most authoritative statement on PPPs was conveyed through the State of the 
Union Address delivered on 13 November 2006 by then President, Festus Mogae. He stated that:

Government has decided that Public Private Partnership (PPP) will be used as a form of procuring and financing infrastructural projects in the public sector. This option will ensure sustainable investment as well as attain development goals in partnership with the private sector. This is in line with the Government's strong belief in the role of the private sector as a development partner (Mogae, 2006a:17, paragraph 103).

Mogae added that PPPs would favourably circumstance the government to deliver development goals in partnership with the private sector and that this move was in accord with the government's strong belief in the role of the private sector as a development partner. He stated that a couple of PPP projects were to be piloted and this included office accommodation for the Ministries of Lands and Housing and Environment, Wildlife and Tourism, Office of the Ombudsman and Land Tribunal and that tenders have been invited (ibid). In addition, he stated that the Central Transport Organisation fleet operations and the proposed International University of Science and Technology were lined up for PPPs (ibid).

As much as the idea of a PPP Policy was given utmost impetus by president Mogae way back in 2006, it was only approved by Cabinet in June 2009 (see Republic of Botswana, 2009). The Cabinet approval paved the way for its launch by the Public Enterprises Evaluation and Privatisation Agency (PEEPA) in early August 2009 (Mooketsi, 2009a). When speaking at the launch, then Assistant Minister of Finance and Development, Keletso Rakhudu, stated that "the PPP Policy and Implementation Framework could not have come at a more appropriate moment in the economic development trajectory of Botswana given the global financial crisis and its profound effect on diamond revenues and the recent cost containment measures announced by the government" (ibid:4). At a later event when talking about wooing investors, he stated that "the PPP policy and Implementation Framework were additional initiatives aimed at creating an investor-friendly-environment" (Mooketsi, 2009b:4).

Despite a long history of discussions on and about PPPs and the subsequent approval of the PPP Policy by Cabinet in June 2009, there has been a slow uptake of PPP initiatives. A few examples of PPPs projects are next given. 
Financing Development through Public Private Partnerships (PPPs) in Botswana 37

\section{Case studies Examples of PPPs projects in Botswana}

(i) Debswana: although predating the PPP Policy, the 45-year-old co-operation between De Beers (the world's leading diamond company) and the Botswana government in the form of De Beers Botswana Mining Company [later renamed Debswana in June 1969] is a PPP (Mohohlo, 2011). As a result of the PPP arrangement, Botswana is the largest producer of diamonds by value in the world and has extracted rent from the diamonds sector to finance economic, social and human development. Botswana, as a consequence, graduated from the list of poor countries to a middle-income country in 1992 (Mogae, 2006b; Mohohlo, 2011).

(ii) Southern African Development Community (SADC) House: funded by SADC states and private capital, the twin-tower building is designed for 250 members of staff and has provision for future expansion for additional 250 members of staff. This, therefore, will translate into a capacity of 400 members of staff (Southern African Development Community, 2010). The Government of Botswana provided a plot of land measuring $11,343 \mathrm{~m}^{3}$ for a 99-year lease agreement. The lease agreement is expected to service and maintain the lease rental fee of BWP2 11, 343.00 per annum (SADC, 2010:9). The Government of Botswana and SADC have undertaken to accept financial liability in the event the project fails. In this regard, the Government of Botswana is the guarantor for the project. What this is means is that, in the event that SADC defaults in paying the Unitary Charges, the Government of Botswana will honour all the outstanding Unitary Charges and, thereafter, SADC will reimburse the Government of Botswana for all the costs incurred (ibid, 2010:9). The Unitary Charge as of 12 October 2007, subject to the US Consumer Price Index (CPI), was USD 337, 430.00 per month. This translates into USD 4, 049, 160.00 per annum for 15 years. The PPP commencement date was 13 August 2009 and, thus, SADC began incurring costs from that date. Going forward, the Unitary Charge will be factored into the SADC budget and additional amounts will be

\footnotetext{
21 Botswana Pula $=0.092$ US Dollar at the time of writing ( 6 April 2016), so, P 11, $340=$ USD 1, 046.82.
} 
drawn from SADC members' contributions as per the agreed formula (ibid 2010:9).

Other PPPs include the Ombudsman's office [a private partner constructed the office accommodation and the government provided office furniture and maintenance services] (see; e.g., KPMG Services, 2013). In a related sense, the second phase of the Botswana International University of Science \& Technology was to be delivered through PPP (Gaotlhobogwe, 2009). However, the global economic crisis put paid to this intention.

Despite the slow uptake of PPPs, there are recent moves towards PPP ventures as the government faces chronic fiscal stress as a result of the global economic crisis (particularly, since 2008, diamonds are not selling well). To illustrate, when officiating at the Botswana Association for Local Authorities $16^{\text {th }}$ national conference themed 'unlocking investment opportunities-modernising service delivery' on 15 March 2015, then Minister of Local Government and Rural Development, Slumber Tsogwane, appealed to local authorities ${ }^{3}$ to put a premium on partnerships with the private sector, to raise funds and ensure their sustainability (Mmegi Business, 2015). Tsogwane underscored the centrality of the PPPs saying that "Public Private Partnerships (PPPs) have the potential to diversify Botswana's economy and create jobs for Batswana, in the process, alleviating poverty and consequently reducing dependence on the government" (ibid:4). Thus, it can be safely concluded that there will be efforts towards the expanded use of PPPs as the government faces a dwindling revenue envelope post-2008. To this end, such example is the Mongala mall in Kanye. The PPP project was officially opened on 26 March 2014 (Botswana Press Agency, 2014b).

\section{Fiscal Stress and the increasing need for PPPs}

Botswana is a minerals-led economy (Jefferies, 1998), so, its fortunes are tied to developments in world primary commodity markets. Its economic fortunes rise and fall in correspondence with the fortunes of world primary commodity markets. Since 2008, diamonds, the primary export earner, are not selling well (see; e.g., Gaolathe, 2009 and Mathambo, 2010-16). Although the diamonds market has slightly recovered, for example during 2013/14, it has not bounced back to pre-2008 levels, thus, this puts Botswana in

\footnotetext{
${ }^{3}$ This refers to councils, both rural and urban.
} 
a precarious revenue situation. To illustrate, according to the 2016/17 Budget Strategy Paper, a precursor to the $2016 / 17$ budget, the country is headed for perilous times. Largely due to the underperforming mineral sector, particularly diamonds, economic growth has been revised down from 4.9 to 2.6 per cent for the 2015/16 financial year (Ministry of Finance and Development Planning, 2015). As a result, total revenues and grants for the revised 2015/2016 budget are estimated at P51.69 billion, a downward revision of 6.7 percent from P55.38 billion in the original budget (Ministry of Finance and Development Planning, 2015). As a result, the revised 2015/2016 budget is now estimated to record a budget deficit of P4.03 billion or minus 2.6 percent of GDP (ibid). Prospects for the 2016/17 financial year are similarly dim. To illustrate, when presenting the 2016/17 Budget Speech, the Minister of Finance and Development Planning, Kenneth Mathambo, forecast budget deficit. He stated that "with an estimated total revenues and grants of P48.40 billion for 2016/2017 financial year, and proposed total expenditure and net lending of P54.44 billion, the net result is an estimated budget deficit of P6.05 billion or 3.8 percent of GDP" (Mathambo, 2016:19).

The above situation galvanised the government into action as amply instanced by the announcement of an Economic Stimulus Programme (ESP) by President lan Khama on 10 October 2015 (Botswana Press Agency, 2015). When formally announcing the ESP when delivering the 2015 State of the Nation Address, President lan Khama stated that the programme was "a holistic action plan for achieving the goals of stimulating economic growth, accelerated employment creation and the promotion of economic diversification" (Khama, 2015:2). The following have been identified as key sectors that will drive the programme: Infrastructure, Agriculture, Tourism and Manufacturing and Services, enabled by the establishment of Special Economic Zones (SEZs) and the Economic Diversification Drive (ibid). Details of the financing of the ESP have been availed to the public in the form of an ESP brochure (Republic of Botswana, 2015). The government is considering many financing options, including dissaving from foreign exchange reserves and PPPs (tapping into private capital (Khama, 2015). In a related vein, 5 October 2015, the NonBank Financial Institutions Regulatory Authority issued the revised Pension Investment Rule [PFR 2] (Non-Bank Financial Institutions Regulatory Authority, 2015). Amongst others, the revised PFR 2 provided the retirement fund industry with the revised quantitative limits on assets to be held by a retirement fund (ibid). Specifically, part 3.6, 'Limitation on Foreign Investment', states that "subject to the transitional rules set out in 
section 6, no fund shall, in respect of its fund investment strategy, invest less than thirty (30) \% of its total assets in Botswana". The effective date of the implementation of PFR 2 was 1 April 2016, therefore, the government is very favourably circumstanced to tap into private capital and, therefore, finance ESP projects.

\section{Suggestions to enhance the financing of development through PPPs}

Given the fact that PPPs are a feature of public policy in Botswana, a few things are worth considering going forward. These are meant to get VfM (Value for Money) from the PPPs.

\section{Legal-Institutional framework}

It is important to ensure that there is an enabling environment for the successful operation of PPPs. Design issues are extremely important lest the PPP model becomes comparable to the traditional public sector procurement model in terms of $\mathrm{VfM}$ (Value for Money), or worse, cost-wise. Botswana does not have to reinvent the wheel in terms of founding an appropriate PPPs legal-institutional framework. Thus, it can benchmark on established PPPs legal-institutional frameworks from places such as South Africa and Nigeria in terms of the PPPs regulation and capacity to carry out PPPs projects.

\section{Peer-learning and bench-marking}

Related to benchmarking on established PPPs legal-institutional frameworks in South Africa and Nigeria and further afield in the UK, Canada and US there is a need to peerlearn and bench-mark best practices. However, this is not to say that the government should adopt copy-and-paste peer-learning and bench-marking from established PPPs regimes. Rather, there is a need to pay regard to contextual issues. That is, while there are general PPP lessons, there are context-specific issues, for example culture and work ethics, which need to be taken into consideration when applying PPPs lessons learnt from outside Botswana.

\section{Ease of Doing Business}

Doing business sheds light on how easy or difficult it is for a local entrepreneur to open and run a small to medium-size business when complying with relevant regulations (The International Bank for Reconstruction and Development/The World Bank, 2015). It 
Financing Development through Public Private Partnerships (PPPs) in Botswana 41

measures and tracks changes in regulations affecting 11 areas in the life cycle of a business: starting a business, dealing with construction permits, getting electricity, registering property, getting credit, protecting minority investors, paying taxes, trading across borders, enforcing contracts, resolving insolvency and labour market regulation (ibid). Botswana was ranked 72 (64.98 points) out of 189 countries in both 2015 and 2016 (64.42 points) and there are concerns with regard some ease of doing business indicators, particularly, delays in starting a business and getting electricity. Even though water deficiency is not mentioned in the 2016 Ease of Doing Business report and past immediate ones, this is another problematic area that militates against the ease of doing business. Thus, there is a need to improve on Botswana's Ease of Doing Business scores and rankings to provide a very favourable and enabling environment for the operation of PPPs.

\section{Global Competitiveness Index}

This is an index of a country's global competitiveness and in 2015, Botswana was ranked 71/140 with a Global Competitiveness Index (GCI) of 4.2/7.0 (World Economic Forum, 2015). In previous years, its rankings and GCls were: 2014-15 (74/144; 4.2/7.0); 2013-14 (74/148; 4.1/7.0); and 2012-13 (79/144; 4.1/7.0). Excepting for slight changes in the sample size, its rankings and $\mathrm{GCl}$ have largely remained the same. As in previous surveys, the most problematic factors detracting from competitiveness were: poor work ethic in labour force (19); inefficient government bureaucracy (12.7); restrictive labour regulations (11.9); access to financing (10.4); inadequately educated workforce (9.3); inadequate supply of infrastructure (7.7); corruption (7.1); insufficient capacity to innovate (6.0); crime and theft (5.1); tax rates (3.8); inflation (2.5); policy instability (1.8); complexity of tax regulations (1.3); poor public health (0.8); government instability/coups (0.4); and foreign currency regulations (ibid). Thus, there is a need for the country to improve its scores and rankings to provide a favourable and enabling environment for the operation of PPP projects.

\section{Project Implementation}

Botswana has a very chequered history of project implementation (e.g., see Lucas, 2008; Mathambo, 2015; Maruapula 2006; 2008; Segaetsho and Mpuang, 2015). Largely, this is due to poor project monitoring and controlling. While the government is in the process 
of establishing a National Monitoring and Evaluation System for Botswana (Botlhale, 2015), there is a need to engender a culture of professional project management, as opposed to accidental project management (for a definition of accidental project management, see; for example, Pinto and Kharbanda, 1995), to better deliver PPP projects.

\section{Conclusion}

PPP arrangements are on the ascendancy in both developed and developing counties. There are seen as the alternative to the [traditional/conventional] public sector public procurement. There is a strong reason to believe that the drive for PPP arrangements in developing countries is going to gain traction due to public sector reforms such as New Public Management, New Public Service and New Public Governance and chronic fiscal stress post-2008. At the same time, there is an increasing awareness that the private sector is not a competitor but a strategic partner in the drive for economic development. Governments are, therefore, leveraging on these smart strategic partnerships. Botswana has adopted PPPs to finance development projects in the wake of public sector reforms such as privatisation and a precarious revenue situation since 2008. Although there has been a slow uptake of PPPs as evidenced by few PPP projects, current trends are indicative of the government's resolve to use PPPs to finance development projects. Finally, there is a need to reform the PPP legal-institutional matrix and the adoption of initiatives such as improving national productivity and bench-marking and peer-learning from the best PPP practices in the world.

\section{List of References}

- African Development Bank Group. 2015. Public-Private Partnerships. Retrieved from; http://www.afdb.org/en/topics-and-sectors/sectors/private-sector/areas-of-focus/publicprivate-partnerships/ (retrieved 30 November 2015).

- Botlhale, E.K. 2014. The case for gender mainstreaming Botswana's privatisation process. Development Southern Africa, 31(6):812-825. 
- Botlhale, E.K. 2015. Monitoring and Evaluating Government Performance in Botswana. Africa's Public Service Delivery and Performance Review, 3(1):5-25.

- Botswana Press Agency. 2000. Citizens to benefit. Daily News, 15 August, p. 1.

- Botswana Press Agency. 2014a. Mongala Mall generates excitement. Daily News, 20 March, p. 4.

- Botswana Press Agency. 2014b. Mongala Mall transforms Kanye. Daily News, 30 March, p. 4.

- Botswana Press Agency. 2015. Economic stimulus programme for backlog. Daily News, 15 October, p. 1.

- Botswana Vision Council. 2010. Vision 2016. Gaborone: Government Printing and Publishing Services.

- BR Properties. 2015. Rail Park Mall. Retrieved from; http://www.brproperties.co.bw/railpark-mall (retrieved 30 November 2015).

- Canadian Council for PPPs. 2010. Public-Private Partnerships. Retrieved from; http://www.pppcouncil.ca/aboutPPP_definition.asp (retrieved 22 April 2015).

- Centre for International and Strategic Studies. 2011. Seizing the opportunity in publicprivate partnerships. Washington DC: Centre for International and Strategic Studies.

- Cheung, E., Chan, A. and Kajewski, S.L. 2009. Reasons for implementing public private partnership projects: perspectives from Hong Kong, Australian and British practitioners. Journal of Property Investment and Finance, 27(1): 81-95.

- Colverson, S. with Perera, O. 2011. Sustainable Development. is there a role for publicprivate partnerships? Winnipeg, Manitoba, Canada: International Institute for Sustainable Development.

- Cruz C.O. and Marques, R.C. 2013. Infrastructure Public-Private Partnerships, decision, management and development. Heidelberg: Springer.

- Dewulf, G., Mahalingam, A. and Jooste, S. 2011. The transition towards a sustainable PPP regime. Available from; http://www.academiceventplanner.com/EPOC2011/papers/dewulf_mahalingam.pdf (retrieved 22 April 2015). 
- Eversheds International. 2014. PPP in Africa. pushing the boundaries. Available from; http://www.eversheds.com/global/en/what/articles/index.page?ArticlelD=en/Africa_group/p pp-africa-pushing-boundaries140714 (retrieved 30 April 2015).

- Farlam, P. 2005. Working Together, Assessing Public-Private Partnerships in Africa. Pretoria: The South African Institute of International Affairs.

- Forrer, J., Kee, J.E., Newcomer, K.E. and Boyer, E. 2010. Public-Private Partnerships and the Public Accountability Question. Public Administration Review, 1(1): 475-84.

- Gaolathe, B. 2002. 2002/03 Budget Speech. Gaborone: Government Printing and Publishing Services.

- Gaolathe, B. 2009. 2009/10 Budget Speech. Gaborone: Government Printing and Publishing Services.

- Gaotlhobogwe, M. 2009. Govt to develop first phase of BIUST alone. Mmegi, 26 January, p. 4.

- Ghobadian, A., Gallear, D., O'Regan, N. and Howard, V. 2004. Future of the public private partnership. In A. Ghobadian, D. Gallear, N. O'Regan. and V. Howard, (Eds.). Public Private Partnerships: policy and experience. Chippenham: Palgrave Macmillan, pp. 271-302.

- Gore, A. 1993. Creating A Government That Works Better and Costs Less New York: Penguin Books.

- Grimsey, D. and Lewis, M. 2007. Public Private Partnerships and Public Procurement. Agenda, 14(2): 171-188.

- HM Treasury. 2012. A new approach to public private partnerships. London: HM Treasury.

- International Monetary Fund. 2004. Public-Private Partnerships. Washington DC: International Monetary Fund.

- International Monetary Fund. 2006. Public-Private Partnerships, Government Guarantees and Fiscal Risk. Washington DC: International Monetary Fund.

- International Project Finance Association. 2015. Benefits of PPPS. Retrieved from; http://www.ipfa.org/industry-resources/benefits/ (retrieved 30 November 2015).

- Jacobson, C. and Choi, S.O, 2008. Success factors: public works and private partnerships. The International Journal of the Public Sector, 21(6): 637-657.

- Jefferis, K. 1998. Botswana and diamond-dependent development. In W. A. Edge and M. Lekorwe (Eds.), Botswana: Politics and Society. Pretoria: JL van Schaik, pp. 301-332. 
- Jones, B.D. 1994. Reconceiving decision-making in democratic politics. attention, choice, and public policy. Chicago: The University of Chicago Press.

- Kashiwagi, D. 2011. Case Study: Best Value Procurement/Performance Information Procurement System Development. Retrieved from; http://pbsrg.com/app/wpcontent/uploads/publications/papers-intro/Case-Study-Best-Value-Procurement-

Performance-Information-Procurement-System-Development.pdf (retrieved 1 March 2015).

- Khama, I. (2015). 2015 State of the Nation Address. Gaborone: Government Printing and Publishing Services.

- KPMG Services. 2013. Botswana Country Report for the SADC-DFRC 3P. http://www.sadcpppnetwork.org/wp-content/uploads/2015/02/Botswana-NI.docx. (accessed 6 April 2016).

- Land, A. 2002. Case Study on Structured Public-Private Sector Dialogue; the Experience from Botswana. Available from; http://ecdpm.org/wp-content/uploads/2013/11/DP-37Structured-Public-Private-Sector-Dialogue-Botswana-2002.pdf (accessed 22 April 2015).

- Lucas, T. 2008. Botswana's implementation problematic: a case for a comprehensive audit, Mmegi, 21 February, p. 10.

- Mannathoko, I. 2012. Public-Private Partnerships. Paper presented at the BOCCIM Business Conference, October 14-17, 2012, Gaborone, Botswana.

- Maruapula, O. 2006. Project Management Practices in Botswana; with aspects of matrix organisations. Gaborone: Rural Industries Promotions Company.

- Maruapula, O. 2008. Facilitative Project Management in Botswana, context interrogation beyond construction. Gaborone: Pentagon.

- Mathambo, K. 2010. 2010/11 Budget Speech. Gaborone: Government Printing and Publishing Services.

- Mathambo, K. 2011. 2011/12 Budget Speech. Gaborone: Government Printing and Publishing Services.

- Mathambo, K. 2012. 2012/13 Budget Speech. Gaborone: Government Printing and Publishing Services.

- Mathambo, K. 2013. 2013/14 Budget Speech. Gaborone: Government Printing and Publishing Services. 
- Mathambo, K. 2014. 2014/15 Budget Speech. Gaborone: Government Printing and Publishing Services.

- Mathambo, K. 2015. 2015/16 Budget Speech. Gaborone: Government Printing and Publishing Services.

- Mathambo, K. 2016. 2016/17 Budget Speech. Gaborone: Government Printing and Publishing Services.

- Ministry of Finance and Development Planning. 2003. National Development Plan 9. Gaborone: Government Printing and Publishing Services.

- Ministry of Finance and Development Planning. 2015. 2016/17 Budget Strategy Paper. Gaborone: Ministry of Finance and Development Planning.

- Mmegi Business. 2015. Tsogwane encourages mutually beneficial PPPs. Mmegi, 15 March, p. 1.

- Mogae, F. 2006a. 2006 State of the Nation Address. Gaborone: Government Printing and Publishing Services.

- Mogae, F.G. 2006b. Mogae takes Diamonds for Development campaign to the US capital. Mmegi, 13 October, p.1.

- Mohohlo, L. 2011. Botswana proves African governments shouldn't go it alone (The Guardian, 5 May 2011). Retrieved from; http://www.theguardian.com/globaldevelopment/poverty-matters/2011/may/05/botswana-public-private-partnershipsprogress (retrieved 30 November 2015).

- Montanheiro, L. 2014. Public-Private Partnerships and Their Economic Contribution. International Journal of Applied Public-Private Partnerships, 1(2); 1-18.

- Mooketsi, L. 2009a. Policy on private-public sector cooperation launched. Mmegi, 7 August, p. 4.

- Mooketsi, L. 2009b. PPP key to wooing investors - Rakhudu. Mmegi, 18 September, p. 4.

- Mpabanga, D. 2011. Public Private Partnerships (PPPs) in Botswana. Journal for Public and Non-Profit Services, 41: 48-65.

- National Council for Public-Private Partnerships. 2016. 7 Keys to Success. Available from; http://www.ncppp.org/ppp-basics/7-keys/ (accessed 6 April 2016).

- Non-Bank Financial Institutions Regulatory Authority. 2015. Circular No. 2 of 2015. Gaborone: Non-Bank Financial Institutions Regulatory Authority. 
- O'Hanlon Health Consulting, O'Hanlon, B. and Jeffers, J.J. 2013. Reference Guide for development of Public Private Partnerships in the Health Sector for Countries in the SADC region. Washington, D.C.: O'Hanlon Health Consulting.

- OECD (Organisation for Economic Co-operation and Development) 2002. From Lessons to Principles for the use of Public-Private Partnerships. Paris: OECD.

- OECD. 2008. Public-private partnerships. in pursuit of risk sharing and value for money. Paris: OECD Publishing.

- OECD. 2013. Increasing private participation in the Southern African Development Community's infrastructure. policy bottlenecks and the way forward (10 April 2013). Retrieved from; http://www.oecd.org/daf/inv/investmentpolicy/IncreasingPrivateParticipationInSADCinfrastructure.pdf (retrieved 30 November 2015).

- Okonkwo, R.l., Ndubusi-Okolo, P. and Anigbogu, T. 2014. Public Private Partnership and Infrastructural Development in Nigeria: a study of Greater Ontisha water scheme in Anambra State. In R.K Nkum and Nani G., Atepor, L., Oppong, R.A., Awere E., and BamfoAgyei, E. (Eds). Procs 3rd Applied Research Conference in Africa (ARCA) conference, 7-9 August 2014, Accra, Ghana, pp. 161-176.

- Osborne, S.P. 2000. Public-private partnerships. theory and practice in international perspective. London: Routledge.

- Pinto J.K. and Kharbanda, O.P. 1995. Lessons for accidental profession. Business Horizons, 38: 41-50.

- Posner, P., Ryu, S.K. and Tkachenko, A. 2009. Public-Private Partnerships: the relevance of Budgeting. OECD Journal on Budgeting, 1:1-26.

- Public-Private Infrastructure Advisory Facility. 2008. PPP Basics and Principles of a PPP Framework. Available from; http://www.ppiaf.org/sites/ppiaf.org/files/documents/NoteOne-PPP-Basics-and-Principles-of-a-PPP-Framework.pdf (accessed 5 April 2015).

- Ramiah, I. and Reich, M.R. 2006. Building effective public-private partnerships: experiences and lessons from the African Comprehensive HIV/AIDS Partnerships (ACHAP). Soc Sci Med. 63(2):397-408.

- Rao, N.T. V. and Vokolkova, V. 2007. Public private partnership in road transport sector in Botswana. Retrieved from; http://www.codatu.org/wp-content/uploads/Public-privatepartnership-in-road-transport-sector-in-Bostwana-N.T.-Rao-V.-Vokolkova.pdf (retrieved 30 November 2015). 
- Republic of Botswana. 2000. Privatisation Policy of Botswana. Gaborone: Government Printing and Publishing Services.

- Republic of Botswana. 2009. Public-Private Partnerships Policy (2009). Gaborone: Government Printing and Publishing Services.

- Republic of Botswana. 2015. Economic Stimulus Programme (ESP); a strategy for employment and growth, 2015 and beyond. Gaborone: Government Printing and Publishing Services.

- Savas, E.S. 2000. Privatization and Public-Private Partnerships. New York: Chatham House.

- Segaetsho, T. and Mpuang, L. 2015. Molepolole bus rank project; the plot thickens, The Botswana Gazette, 5-11 August, p. 2.

- South African National Treasury. 2004. Public-Private Partnership Manual. Pretoria: South African National Treasury.

- Southern African Development Community. 2010. SADC Headquarters. Gaborone: SADC.

- The International Bank for Reconstruction and Development/The World Bank. 2015. Doing Business 2016; Botswana. Washington DC: The International Bank for Reconstruction and Development/The World Bank.

- Trafford, S. and Proctor, T. 2006. Successful joint venture partnerships: public -private partnerships. The International Journal of the Public Sector Management, 19(2):117-129.

- United Nations. 2008. Guidebook on promoting good governance in public-private partnerships. Geneva: United Nations.

- United Nations. 2011. A Guidebook on Public-Private Partnership in Infrastructure. New York: United Nations.

- Walker, C., Mulcahy, J., Smith, A., Lam, P.T.I. and Cochrane, R. 1995. Privatized Infrastructure, The BOT approache. London: Thomas Telford.

- World Economic Forum. 2015. The Global Competitiveness Report 2015-2016. Geneva: World Economic Forum.

- Zucker, L. 1977. The role of institutionalization in cultural persistence. American Sociological Review, 42:726-43. 
Financing Development through Public Private Partnerships (PPPs) in Botswana 49

AUTHOR'S CONTACT:

BOTLHALE, E.K.

University of Botswana

Email: BOTLHALE@mopipi.ub.bw 